
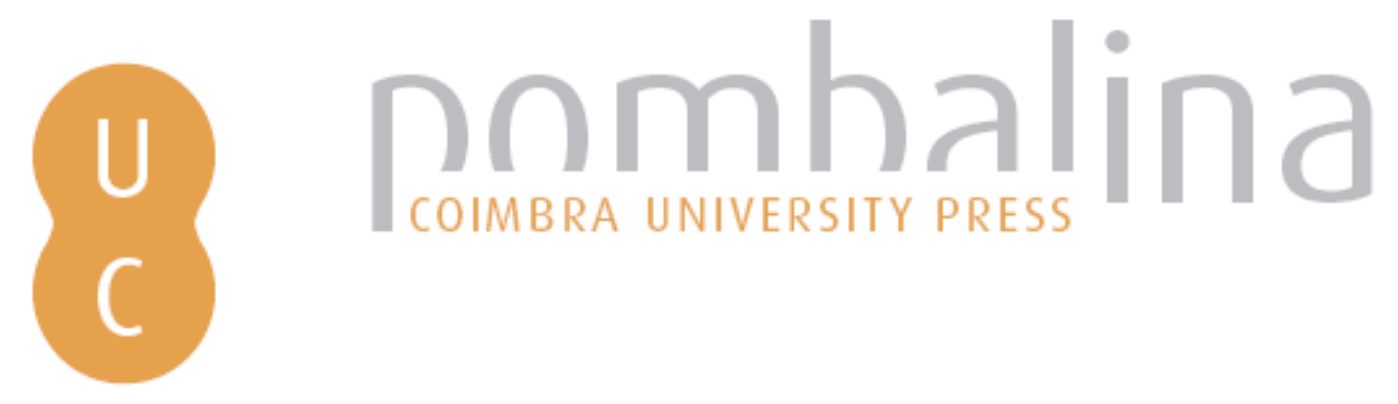

\title{
Senior students in the knowledge society: a curricular program of digital literacy
}

\author{
Autor(es): $\quad$ Varregoso, Isabel; Pimentel, Luísa; Santos, Filipe; Rodrigues, Carina; \\ Cainço, Paula; Leal, Sandra
}

Publicado por: Imprensa da Universidade de Coimbra

URL

persistente: URI:http://hdl.handle.net/10316.2/32514

DOI: $\quad$ DOI:http://dx.doi.org/10.14195/978-989-26-0732-0_12

Accessed : $\quad$ 26-Apr-2023 08:05:43

A navegação consulta e descarregamento dos títulos inseridos nas Bibliotecas Digitais UC Digitalis, UC Pombalina e UC Impactum, pressupõem a aceitação plena e sem reservas dos Termos e Condições de Uso destas Bibliotecas Digitais, disponíveis em https://digitalis.uc.pt/pt-pt/termos.

Conforme exposto nos referidos Termos e Condições de Uso, o descarregamento de títulos de acesso restrito requer uma licença válida de autorização devendo o utilizador aceder ao(s) documento(s) a partir de um endereço de IP da instituição detentora da supramencionada licença.

Ao utilizador é apenas permitido o descarregamento para uso pessoal, pelo que o emprego do(s) título(s) descarregado(s) para outro fim, designadamente comercial, carece de autorização do respetivo autor ou editor da obra.

Na medida em que todas as obras da UC Digitalis se encontram protegidas pelo Código do Direito de Autor e Direitos Conexos e demais legislação aplicável, toda a cópia, parcial ou total, deste documento, nos casos em que é legalmente admitida, deverá conter ou fazer-se acompanhar por este aviso.

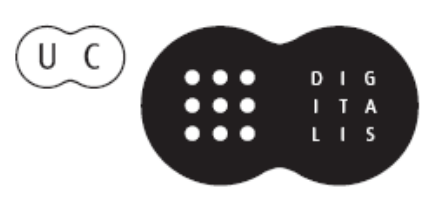


MPRENSA DA

UNIVERSIDADE

DE COIMBRA

COIMBRA

UNIVERSITY

- PRESS 


\title{
SENIOR STUDENTS IN THE KNOWLEDGE SOCIETY:
}

\section{A CURRICULAR PROGRAM OF DIGITAL LITERACY}

\author{
Isabel Varregoso ${ }^{32}$, Luísa Pimentel, Filipe Santos, \\ Carina Rodrigues, Paula Cainço, Sandra Leal
}

\begin{abstract}
As part of its educational mission, the Polytechnic Institute of Leiria has been developing a lifelong learning project, Program IPL 60+, where senior students are provided with learning opportunities on themes of interest to this age group. These seniors, being also a part of the so-called Knowledge Society, must seek to know and learn the "new literacies" to be and feel part of this society. Therefore, Program IPL 60+ includes "computer literacy "as part of the curricular offer of this project.

Designing a curriculum in "informatics" that appeals to this age group and implementing it in a course offers several challenges. Besides the specific profile of students in this age group, which requires specific methodological choices, we must frame the course contents taking into consideration the needs and interests of each student, so that each one can make an adequate appropriation of the technologies. This issue presents a greater challenge when we consider that a significant part of this population does not know a priori all these technologies and their potential and, thus, cannot express their interests to the trainers concerning what would they like to learn.

This paper presents a proposal to offer ICT training for this audience, based on an informatics course of 3 academic years. This proposal comes from the experience of the authors in this project and is based on some theoretical frameworks on methodological issues, seeking to make a compromise between the expectations
\end{abstract}

32 Polytechnic Institute of Leiria, Portugal

Email: isabel.varregoso@ipleiria.pt 
of students, meeting the interests directly manifested, and the introduction of new concepts and potential of the technologies that they generally don't know. We observed that students try to appropriate the material learned, giving it a personal meaning and a creative use and therefore, a compromise between the subjects that students wish to learn and the introduction of new "unknown" subject material can be advantageous.

Keywords: Digital Literacy; Lifelong Learning; Senior Students.

\section{Project IPL 60+}

As part of its educational mission, the Polytechnic Institute of Leiria has been implementing a lifelong learning project, Program IPL $60+$. This project provides educational and social-cultural opportunities to senior students, focusing on the themes of interest of this age group. One of the project's main objectives is to implicate senior students pro-actively in their own well-being in a perspective of citizenship and social well-being in order to help their social inclusion, changing the conceptions of seniority (IPL, n.d.).

This project, framed under the Polytechnic's Strategic Plan 2007-2011, is aimed at the development of the community and region, providing and promoting learning and cultural activities for new audiences (as shown in Figure 26) and to contribute to gerontological research, development and innovation (Pimentel et al., 2012).

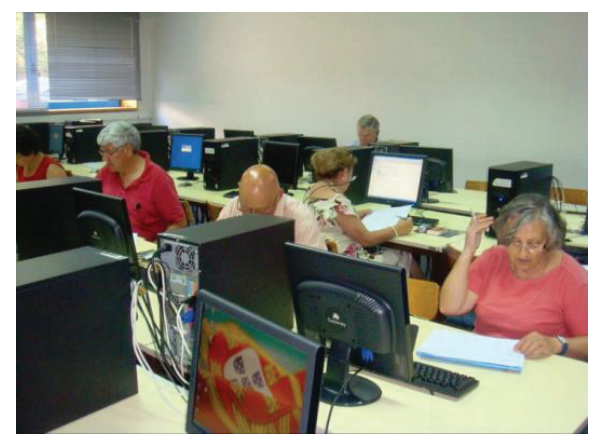

Figure 26: Seniors citizens in an informatics class. 


\section{Senior Students \& Digital literacy}

\section{The European demographic changes}

According to some studies, the number of elder citizens will reach 58 million in Europe by 2050 representing $77 \%$ of the current population of the European Union (Malanowski, Özcivelek \& Cabrera, 2008). In Portugal alone, the United Nations foresee that $37 \%$ of the population will be 60 years old or older by 2050 , with the age group of 80 or older being about $26 \%$ of the population. Such profound changes in the European countries' demographical pyramid demand the emergence of social answers at community level that integrate seniors socially in that community.

Until recently it was accepted that man's biological and psychological evolution could be seen through three stages: infancy (as a stage for development and preparation for adult life), adult (as the active life stage, dedicated to production) and senior (as a retirement stage). Seniors were seen from a set of psychobiological theories that interpreted old age as a stage of degeneration (the neurophysiological factor of aging). But currently we know that it is precisely the lack of exercise that leads to deterioration. We must therefore use the specific characteristics that this population has (such as retirement, health, available free time and loneliness) to implement both educational and animation projects that take into account their experience, knowledge and competences. Therefore, we may say that these two solutions, education and animation, may help in seniors' social integration.

The World Health Organization (WHO) also emphasizes that although chronological age is an indicator of senescence, the importance of understanding "getting old" as something personal and multifactorial should be highlighted. As Silva and Caldas (2007) put it:

"[...] it is important to recognize that chronological age is not a precise indicator of the changes that go along with aging. There are significant changes related to health status, participation and independency levels between elders that have the same age. Authorities need to 
consider those variations when formulating policies and programs for such elder populations. Enforcing comprehensive social policies based on chronological age alone can be discriminatory and counterproductive to well-being in the third age" (Silva \& Caldas, 2007).

Therefore, the active participation of senior citizens in the community could be promoted in two ways: one is by implementing socio-cultural activities, as seniors have longer idle times than the rest of the population (as most of them are retired), enabling individuals and groups to select activities and experiences that fit their own needs, interests and preferences, promoting good general health and wellness (Cabeza, cit. in Trilla, 1998). The other way lies in educational activities. As Simões (2006, p. 12) recalls:

"Old people today are not only healthier but also more educated, and will be increasingly so in the future. However, experience shows that education calls for more education in the sense that the educational level of older people triggers increased demand for education."

According to the studies in this area, older people still maintain their ability to learn, a reasonable mental plasticity and the experience and knowledge acquired and built during life (Simões, 1999). There are still some concerns about seniors" "lack of memory", but the identified problems are not due to loss of "storage capacity", but "[...] the processes that ensure the transfer of information from temporary storage for the long-term memory, and its recovery" (Marchand, 2005). In another words, at this age it is essential to create participation processes, create spaces for group communication, taking elders to collaborative activities and thus giving them a healthy aging.

In 1986 UNESCO emphasized the importance of conceiving educational and cultural activities targeting the elderly "[...] To better assume their own aging [...] [...] to make societies benefit from their long experience" (Silvestre, 2003). Senior educational opportunities fall under the "Adult Education" pedagogical category, which moves away from traditional 
school models and emphasizes the importance of new learning contexts. This way, institutions try to go beyond formal education, recognizing the educational role of non-formal and informal learning activities. Therefore, projects and programs have been born, taking advantage of the amount of seniors' free time and that are adequate to their interests, taking into account their life path.

\section{Knowledge Society and digital literacy}

Currently education is seen as a global and permanent process, not limited to a unique time and space in human life. The Portuguese Ministry of Science and Technology, in its Green Book for the Society of Information in Portugal (MCT, 1997), emphasized educational objectives marked by the demands of lifelong learning. These are translated in terms of four fundamental apprenticeships: learn to know, learn to do, learn to live in society and learn to be. In this sense, it is fundamental that the educational system prepare individuals in how to live together and interact with new technologies (Meirinhos, 2000).

Digital inclusion is being promoted as a necessary, new literacy (digital literacy). The lack of this literacy excludes the citizen from the culture of the information society. The threat of info-exclusion is enormous, resulting in disadvantages in terms of citizenship (Marques, 1998). Thus, for a full exercise of the rights of citizenship in the current information and knowledge society, it is urgent to ensure that the greatest number of citizens have access to the new Information and Communication Technologies (ICT).

This information society has been imposing a new concept of literacy. Previously, a literate person was one who could read and write but today, this know-how is insufficient to be able to access information. Thus, it is important that seniors have access to digital literacy. For that matter, the Resolution of the Council of Ministers No. 155/2007, establishes the guidelines for government and public services and central government website accessibility by citizens with special needs, recognizing that "The 
information society technologies represent to all people with special needs (disabled and elderly) a means towards inclusion and social participation by excellence" (DR, 2007).

Considering that the information and communication technologies are an integral part of people's lives (leisure, communication, work), it is pertinent provide the elderly with the same opportunities, through education. Machado (in Silva and Caldas, 2007) states that "Seniors who return to school, will not only be intellectually enriched, but they will also have chances of modifying and creating opportunities for dialogue, exchange of knowledge, social participation (...) individuals must use all its possibilities to learn and improve". According to Papert (1997) "the real contribution of digital media for education is the flexibility that could allow each individual to find personal paths to learn." This means that technology must serve the interests of seniors. As this age group is also a part of the so-called Knowledge Society, seniors must therefore seek to know and learn the "new literacies" to be (and feel) part of this society and Program IPL 60+ includes "computer literacy" as part of its curricular offer.

\section{Construction of an ICT curriculum for seniors}

\section{Challenges}

The construction of an ICT curriculum tailored to the specific needs of seniors, using adult learning methodologies, has been a challenging process. One of the first challenges was to find a definition of "significant learning", defended the models of adult education, when elders are involved. Malcolm Knowles (in Ferreira, 1999) was the first to talk about the concept of andragogy, and the term adopted by UNESCO in 1976 to designate "(...) art and science of helping adults to learn."

In the processes of adult learning, there are the following assumptions: learning by interests and motivations; active participation in activities; relationship between learning and experience, immediate application of 
learning, respect for diversity and mental processes (Silva, 2002). The fundaments of adult learning theory are based primarily in the needs and interests of adults, having a focus on the learner, valuing their role of prior experience and will and motivation to learn.

Also, the concept of non-formal education plays an important role in the IPL $60+$ design of its ICT curricula, as it aims to address the needs and specific interests of the public. We had to incorporate active and participatory methodologies, contents that are generally contextualized, with class activities that require few or no academic pre-skills.

However, this age group was not born in the information society and thus cannot have a correct perception of the relevance or importance of most of the content or tools of a digital society. Thus, it is appropriate to balance the (pre) concepts of this age group concerning technology (i.e. their "interests") with the contents or tools that they do not know but that the teachers considered to be promoters of an active citizenship. For example, Social Networks or Photo Sharing services, such as Picasa, are relatively unknown to this age group but very popular after apprehended.

We also tried to create an ICT program that balanced the socio-cultural objective of the IPL $60+$ with its educational objective. In this sense, the digital tools to be learned should make the students learn better but also to better integrate them in socio-cultural activities.

Concerning the educational side of the ICT program, we tried, as the current prevailing theories in the field of adult education suggest, to use their life experiences as a fundamental starting point: the critical importance of the knowledge acquired through life and the role of experience should be an anchor in the production of new knowledge (Canário, 2000). We tried to look at the life paths taken by the seniors that are in this program and tried to identify, for the benefit of learning, the situations, professions, contexts, experiences, different types of formalized training, skills and knowledge they had acquired (Canário, 2000). This pedagogical approach makes learning more valued, as the experiential heritage of each is the most important resource for learning new things.

Therefore, we survey the seniors that enter in the program, concerning the subjects they would like to learn, but we also, when teachers are in 
classes with them, invited them to explore the contents of the disciplines to meet their needs, interests and motivations.

\section{A first course in basic competences on ICT}

An initial course in informatics must focus on what might be the "Basic ICT competences" for digital literacy (to be part of the information society). Thus we have designed a curriculum based on the Government's Decree Law $\mathrm{n}^{\circ} 140 / 2001$ (DR, 2001) where, by recognizing the importance of ICT, the Diploma of Basic Competences of Information and Communication Technologies was created. These competences are "write, print and save a text", "search for information on the Internet" and "send and receive an email message". Thus, in the context of the classroom, activities are developed by performing tasks such as "Create a folder and give it a title; Type, save and print a given text; Access to the World Wide Web; Enter into a search engine of choice; Research on a given theme and print one of the respective pages; Enter the e-mail box; Read a received message and print it; Send a message by attaching the previously typed text." (DR, 2011).

This introductory course takes one academic year.

\section{A course on Multimedia and Web 2.0}

We have designed one other ICT course aimed at seniors who concluded the one-year introductory course and have, therefore, the basic competences of digital literacy. This course concerns Web 2.0 technologies, focusing on blogs as educational tools. Blogs are used successfully in constructivist educational settings that see students as creators of knowledge and see learning as a social process of negotiation and construction (Jonassen, 1999).

In a first stage, seniors were taught some of the most popular multimedia creation tools, so that they could produce contents that could 
later be used in social media. The students brought to class their cameras (with photos on them) and learned how to transfer their photos to the computer. They also learned how to create slideshows in Windows Movie Maker with their photos (Figure 27) and to compress the movie to be able to send it by e-mail to their family. Finally, students also learned how to introduce those photos and movies in content sharing services, such as Picasa and YouTube.

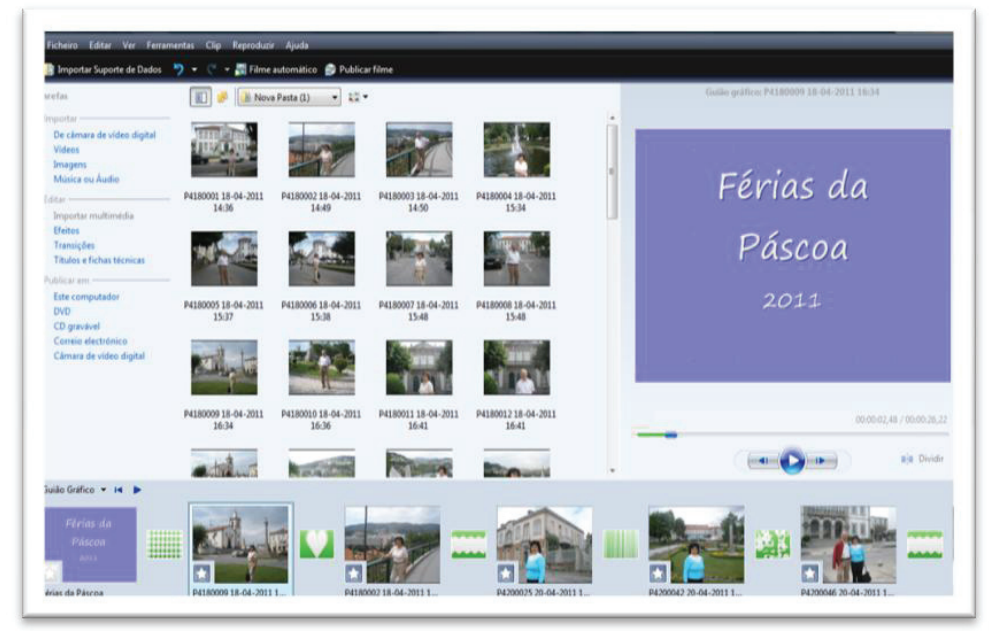

Figure 27: A senior edits a movie in Windows Movie Maker.

By seeing that their photos and videos were now online, students began to feel the web 2.0 paradigm, as teachers now explained how the web had evolved into an environment of both information consumption and production. To help students consolidate this vision, teachers encouraged students to visit several online Portuguese newspapers that allowed visitors to make comments. This strategy made students experience first-hand one of the simplest roles of a "content producer": the student as commentator. By commenting on other people's contents (in this case, news from a newspaper) students saw that their opinion was taken into account in the current Internet.

Our methodological strategy for introducing blogs was, therefore, to give students the opportunity to explore several roles of "information producers", from the most simple to the most complex. For example, 
another site where students were commentators was the teacher's ICT class blog (http://60mais.wordpress.com/). This approach had a double purpose, as it was also aimed at making them experience the feeling of how a small, community blog could enhance the sense of belonging to a virtual community: by reading comments made by people they knew (the other seniors of the class) and commenting back, they began to have a sense of belonging to a virtual "social network".

The next step was to give students a role in which they had more privileges: as co-authors (or guest authors) in a community blog. Teachers created, therefore, a class blog (http://projecto60mais.blogspot.com/) where each student could simultaneously be an author (by inserting posts) or a commentator (by commenting on other senior's posts).

Finally, each student was taught how to build their own individual blog and thus play the role of its administrator. Having total control of a platform that allowed them to be "publishers", students had the opportunity, if they wanted to, to use blogs as tools to support their learning, use them as some form of socialization platform, or content authoring platform (ex: hobbies). Full control of a blog also allowed each student to invite others to participate in it, giving them some kind of editing privileges.

As we imposed no themes on their blogs (to have a pedagogical scenario of significant learning), we observed that seniors used blogs for very different purposes: most seniors used the blog as a way of sharing content with other colleagues (although not educational content). In this sense, they would usually put "entertaining content" (musical videos from YouTube), "social content" (photos of class dinners, meetings, and parties) and "hobbies" (recipes, paintings). Only one senior, who was enrolled in the program "New Opportunities", used his blog as a repository of educational content, in the strict sense of developing a life portfolio (Barreto \& Santos, 2011). Some of the blogs that were created are seen in Figure 28. 

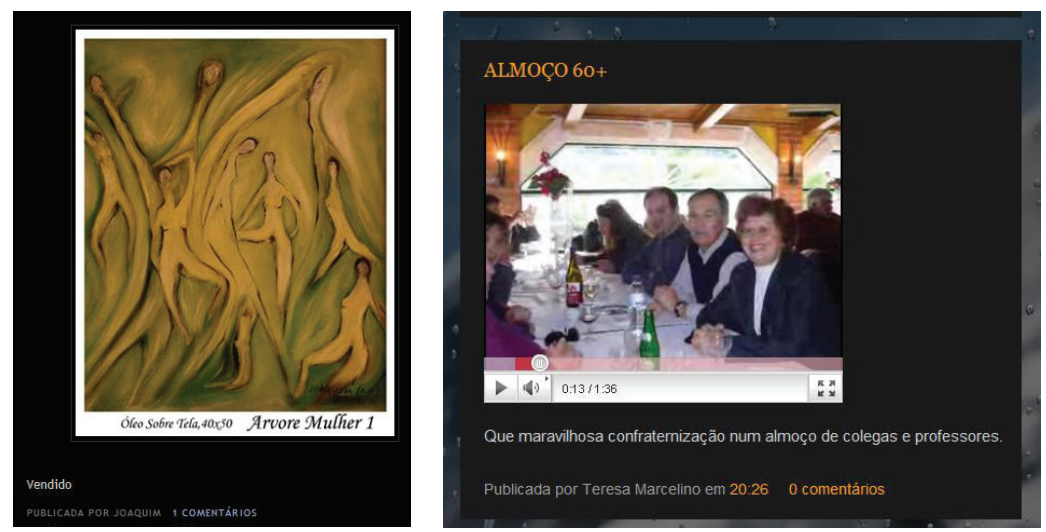

Figure 28: A blog of a senior's paintings (left) and another with a video of a class informal lunch (right).

The ICT courses, both the introductory one and the intermediary one (multimedia and web 2.0), don't have a component where the student's competences are evaluated. Students don't do tests and are not assessed by the teachers in any way, as happens in most formal and non-formal scenarios. Still, students are encouraged to make self-assessments. These assessments are important, in the authors' opinion, as they have an impact on their choices of ICT curricula in the next school year. Some students take the same course twice, either because they enjoy a specific part of the curricula (ex: photo editing) or because they think that they had several limitations that didn't allow them to succeed as well as they wished, and want to take the course again with a fresh perspective and stronger confidence.

\section{Trad'Inovações}

Besides these "traditional" ICT courses, Project IPL 60+ also has an ICT course that runs in parallel with the others, but which is different in its design philosophy. This course is, in fact a project, Project Trad'Inovações, one that aims to gather seniors on the issues of Portuguese traditions and make students learn, socialize and share knowledge and experience 
on this topic through the use of ICTs. In other words, the project aims to develop skills in ICT in the context of archiving and discussing some Portuguese traditions. Trad'Inovações is aimed at people aged over 50, motivated to learn, socialize, share knowledge and experience, who have a taste for learning technologies and Portuguese popular traditions. The people attending this project range, in terms of educational levels, between medium/high, served as qualified professionals and come with high expectations of the Project.

This project began with the following objectives in mind:

- Perpetuate the traditional and popular culture, acknowledging the traditions of the Portuguese people, living them and recreating them through ICT and innovative situations;

- Create a dynamic intergenerational approach to traditional and popular culture, putting generations in interaction - children, young adults and the elderly;

- Share knowledge and practices on the folklore of several countries to understand and accept cultural difference, appreciation of local and regional identities and the promotion of values such as fraternity and universality;

The pedagogical approach of the project is a constructivist one, since the sessions are based on the use of active methodologies to develop democratic skills and attitudes, to encourage the participation and cooperation in groups, solve problems and develop oral communication and technology skills (Marques, 1999). Project activities are also oriented according to the principles of adult education. These start from a non-formal educational strategy, from the needs and specific interests of key actors, and the use of active and participatory methodologies (Jacob, 2007). During the sessions, the key is to combine the preferences of seniors with technological learning, and respect the rhythm of each one, because only then will they be motivated to continue their journey in this area (Morrison, J., Barnett, S7D).

Seniors are bearers of knowledge and, when queried, they reflect enormous wisdom. Throughout the classes, they are invited to explore new technological tools while working on significant topics, such as 
festivals, processions, costumes, legends, food, customs and popular wisdom, among others. The digital tools that are explored in class are chosen according to their interests and needs, and are divided into two distinct categories: offline tools (Office, Photostory, MovieMaker, Picasa, among others) and online tools (Facebook, Blogs, Slideshare, Youtube, Storybird, Google Docs, Prezi, Slideshow, etc). Figure 29 shows one of the blogs produced under this project.

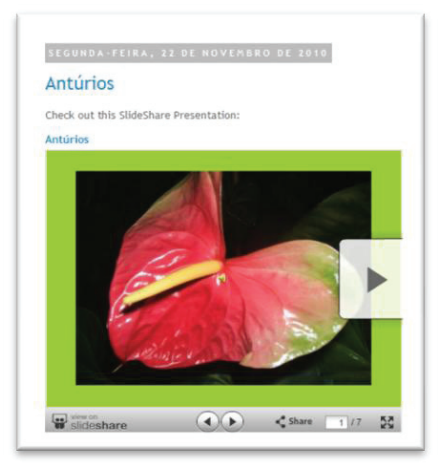

Figure 29: A blog entry on flowers.

The assessment is a fundamental process that serves to assess whether the objectives are being achieved and whether the results are meaningful.

The project's webpage (www.tradinovacoes.blogspot.com) is also used to share knowledge with the community (children, adults and seniors) by publishing the seniors' works made during classes. It is a way to share knowledge and apprenticeships with the community (Rodrigues \& Varregoso, 2011; Rodrigues, 2009). The project has also a space in the Institute's E-Learning platform, a space that is used mainly as a repository of resources, but also where seniors participate in forums, asking questions and raising doubts. It is still in an early stage.

\section{Conclusions}

In this article we have presented the principles that guided the design of several ICT courses for senior students, under a project that aims 
to provide seniors with educational and socio-cultural opportunities in order to make them active participants in the information society, promoting their social inclusion. These courses offer a curriculum that aims to teach students digital tools based on their interests, experiences and expectations, but also by providing them with opportunities to explore new unknown tools that, in the authors' opinion, can be used to have an active role in the information society.

The seniors have been giving some feedback on the courses, either informally and formally (surveys) that lead us to conclude that the courses are pertinent and interesting. Still, we expect to elaborate a more holistic evaluation of the project (on the ICT learning perspective) in the near future.

\section{References}

Barreto, A., \& Santos, F. (2011). Redes Sociais e Formação ao Longo da Vida: Uma parceria Grundtvig. In J. Sousa, M. Meirinhos, A.G. Valcárcel, L. Rodero (Eds.), Actas da $1^{a}$ Conferência Ibérica em Inovação na Educação com TIC (pp. 135-144). Bragança, Portugal: Instituto Politécnico de Bragança.

Canário, R. (2000). Educação de Adultos: Um campo e uma problemática. Lisboa: Educa.

DR (2001). Decreto Lei $n .^{\circ}$ 140/2001, Diário da República I série-A. Retrieved January 27 , 2012, from http://www.umic.pt/images/stories/publicacoes/DL\%20140\%202001.pdf.

DR (2007). Diário da República $n^{\circ} 190$ Série I de 02/10/2007, Resolução do Conselbo de Ministros $n^{\circ}$ 155/2007 de 02-10-2007. Retrieved January 27, 2012, from http://dre.pt/ pdf1sdip/2007/10/19000/0705807058.pdf.

Ferreira, P. (1999). Guia do animador: Uma actividade de formação (2nd Ed.). Lisboa: Multinova. IPL (n.d.-1). IPL 60+: Quem somos? Retrieved January 27, 2012, from http://60mais.ipleiria.pt/quem-somos/.

Jacob, L. (2007). Animação de Idosos (3rd Ed.). Lisboa: Ambar.

Jonassen, D. (1999). Designing construtivistic learning environments. In C. M. Reigeluth (Ed.), Instructional-design theories and models: A new paradigm of instructional theory (pp. 215-239). Mahwah, NJ: Lawrence Eribaum Associates.

Malanowski, N., Özcivelek, R., \& Cabrera, M. (2008). Active Ageing and Independent Living Services: The Role of the Information and Communication Technology. Luxembourg: Institute for Prospective Technological Studies, European Community.

Marchand, H. (2005). Psicologia do adulto e do idoso (2nd Ed.). Coimbra: Quarteto.

Marques, R. (1999). Modelos Pedagógicos Actuais. Lisboa: Plátano Edições Técnicas.

Marques, R. (1998). Os Desafios da Sociedade de Informação. In R. Marques et al., Na Sociedade da Informação: O que aprender na escola? (pp. 11-32). Porto: Asa Editores. 
MCT. (1997). Livro verde para a Sociedade da Informação em Portugal. Lisboa: Ministério da Ciência e da Tecnologia.

Meirinhos, M. (2000). A escola perante os desafios da Sociedade da Informação. Encontro As Novas Tecnologias e a Educação. Bragança: Instituto Politécnico.

Morrison, J., Barnett, A. (s/d). Older people, technology and community. Independent Age. Calouste Gulbenkian Foundation.

Papert, S. (1997). A família em rede. Lisboa: Relógio d'água Editores.

Pimentel, L., Varregoso, I., Faria, S., \& Comprido, A. (2013, in press). The IPL 60+ Program: A singular case of senior education in a intergenerational context. In A. L. Oliveira (Coord.) et al., Promoting conscious and active learning and aging: How to face current and future challenges?. Coimbra: Imprensa da Universidade de Coimbra.

Rodrigues, C., \& Varregoso, I. (2011). Trad'Inovações: Educational Iniciative with adults in Politechnic Institute of Leiria. Internacional Conference on Education and New Learning Technologies (EDULEARN). Barcelona: Spain.

Rodrigues, C. (2009). Animação de Séniores: Uma iniciativa educativa numa Universidade Sénior. (Master dissertation). Retrieved January 27, 2012, from http://repositorio.ul.pt/ handle/10451/921.

Silva, S., \& Caldas, P. (2007). Inclusão digital para as pessoas da Terceira Idade. Retrieved January 27, 2012, from: http://portal.uninove.br/marketing/cope/pdfs_revistas/dialogia/ dialogia_v6/dialogia_v6_4131.pdf.

Silvestre, C. A. S. (2003). Educação/Formação de Adultos, como dimensão dinamizadora do sistema educativo/formativo, Colecção Horizontes Pedagógicos, 12(2), 7-27. Lisboa: Instituto Piaget.

Simões, A. (2006). A nova velhice - um novo público a educar. Porto: Ambar.

Trilla, J. (1998). Animação Sociocultural: Teorias e Programas e âmbitos. Lisboa: Horizontes Pedagógicos. 